\title{
Ratchet Effects in Currency Substitution: An Application to the Kyrgyz Republic
}

\author{
JOANNES MONGARDINI and JOHANNES MUELLER*
}

Currency substitution has been a common issue in the design of monetary policy in most transition economies. This paper analyzes the persistence of this phenomenon in the Kyrgyz Republic up to start of the Russia crisis by including a ratchet variable in the model specification. It concludes that, while some degree of persistence was present in the allocation of bank deposits at that time, currency substitution in the economy at large had not yet reached a point where reversing it would have been costly. [JEL: E41, E52, F31]

his paper analyzes the currency substitution (CS) process in a country of the former Soviet Union (henceforth called $\mathrm{BRO}^{1}$ ), the Kyrgyz Republic, from the introduction of the national currency in May 1993 to October 1998, three months after the Russia crisis hit the Kyrgyz economy. ${ }^{2}$ The Kyrgyz Republic is an interesting case since the ratio of foreign currency deposits to total deposits has risen sharply and hovered at around 40 percent since early 1997, notwithstanding considerable progress in macroeconomic stabilization during this period. The Kyrgyz case is symptomatic of similar developments in other BRO transition

\footnotetext{
*Joannes Mongardini and Johannes Mueller are Economist and Senior Economist, respectively, in the European II Department of the IMF. The authors would like to thank, without implication, Oleh Havrylyshyn, Julian Berengaut, Hugh Bredenkamp, Thanos Catsambas, Jens Dalsgaard, and two anonymous referees for helpful comments on earlier drafts. Sepideh Khazai also provided invaluable research assistance.

${ }^{1}$ Baltics, Russia, and other countries of the former Soviet Union.

${ }^{2}$ Given the central role of the ratchet effect in the present study, the analysis does not go beyond October 1998, as the Russia crisis has temporarily halted the process of macroeconomic stabilization in the Kyrgyz Republic and induced a renewed phase of currency substitution. A major banking crisis added further distortions in early 1999 .
} 
economies, which despite the restoration of growth and rapid disinflation have generally experienced persistently high and, in some cases, rising CS ratios.

Such developments seem to be consistent with evidence from Latin American and other countries where factors that are typically considered conducive to a decline in the CS ratio-moderate inflation, resumption of growth, stability of the exchange rate, and a relatively calm political situation-have generally led to a reduction in the $\mathrm{CS}$ ratio only after long lags. However, the BRO experience appears to run counter to the developments in some Central and Eastern European transition economies, which after successful macroeconomic stabilization have experienced a decline in their CS ratios, such as Poland.

Against this background, this paper identifies the determinants that have driven the CS process in the Kyrgyz Republic during the five years leading to the onset of the Russia crisis, including such factors that have traditionally been used in CS studies, i.e., the interest rate differential and the expected depreciation rate. However, based on Mueller (1994), the econometric analysis goes beyond the conventional CS literature by explicitly addressing the persistence in the use of foreign currency. This hysteresis is modeled through the inclusion of a ratchet variable, which implies an asymmetric substitution process between domestic and foreign currency. The persistence in the use of foreign currency is explained by the fixed costs of introducing "inflation-beating" money management techniques; once these fixed costs are overcome, there are few incentives for agents to switch back to the domestic currency even after macroeconomic stability is regained.

A second feature of this paper is that it experiments with a second, more comprehensive, definition of currency substitution by using a broader definition of the CS ratio that includes the estimated amount of foreign and domestic cash circulating in the Kyrgyz Republic, based on flow data and a recent survey undertaken by the National Bank of the Kyrgyz Republic (NBKR). By including cash, the CS ratio rises from just above 10 percent in May 1993 to slightly above 20 percent in October 1998, exhibiting a continuous, albeit less pronounced, upward trend than the deposit-based CS ratio.

The econometric results indicate that the interest rate differential and the depreciation of the exchange rate are significant CS determinants in the Kyrgyz economy. Moreover, while there may be a ratchet effect in the currency allocation of deposits, such an effect cannot be detected in the broader CS definition including cash. This suggests that the economy as a whole has not yet reached a degree of CS that would make the process asymmetric and difficult to reverse, implying that monetary policy may still have an impact on the portfolio decisions of the private sector. However, given the significance of the ratchet variable for the deposit-only CS ratio, particularly strong policies would need to be pursued over an extended period of time so as to convince deposit holders to switch back to som-denominated assets.

The paper is structured as follows. Section I illustrates the extent of CS in the BRO transition economies, pointing to the possible presence of a ratchet effect and providing a brief theoretical background for, and an overview of, its use in other empirical studies. Section II focuses on the CS process in the Kyrgyz Republic and describes the two CS definitions used in this paper. Section III 
describes the econometric model and the estimation results, while Section IV provides some general conclusions and policy implications.

\section{Evidence of Currency Substitution in BRO Countries ${ }^{3}$}

Currency substitution has been a feature of transition economies in the BRO during the last few years. ${ }^{4}$ The process began at the time when these countries lifted restrictions on foreign currency holdings as part of their efforts to liberalize their economies. In general, the use of foreign currency also reflected a one-time stock adjustment, given the former Soviet Union's central allocation of all international trade through specialized institutions and the strict prohibition on domestic residents to hold foreign currency.

Beyond these factors, though, the increasing use of foreign currency also appears to mirror the attempts of economic agents to hedge against inflation or exchange rate depreciation during periods of large macroeconomic imbalances at the beginning of the respective country's reform and adjustment process. In this context, permitting foreign currency deposits may have also served as a vehicle to foster financial intermediation and financial deepening at a time when banking systems were still considered fragile, thereby laying the foundation for the expansion of commercial banks' operations.

Depending on the extent and speed with which restrictions on foreign currency holdings were lifted, the CS ratios in BRO countries rose rapidly, from virtually nil at independence to an unweighted average of about 35 percent for all BRO countries at end-1995. However, as shown in Figures 1 to 3, by end-1995, there is a considerable variation in the CS ratio across countries: from below 25 percent in Estonia, Moldova, Uzbekistan, and Turkmenistan to 50 percent or above in Armenia, Azerbaijan, Latvia, and Georgia. Moreover, while seven countries experienced a further increase in their CS ratio by mid-1998-with large increases recorded for Armenia, Azerbaijan, Georgia, and Turkmenistan - the CS ratio declined in six other countries, particularly in Belarus, Kazakhstan, and Ukraine. Overall, the unweighted average CS ratio of the sample countries rose to about 40 percent by mid-1998.

The way in which countries induced a reduction in their respective CS ratio varied considerably. Some countries resorted to tighter restrictions on foreign exchange holdings, such as Belarus and Ukraine. The latter, for example, introduced a multiple exchange rate regime and tightened the surrender requirements in 1993. Other countries enjoyed the first outcome of their adjustment efforts, like Kazakhstan and the Baltic republics. These countries rapidly introduced a currency reform and pursued tight fiscal and monetary policies, in the case of Lithuania and Estonia anchored by a currency board, which led to a rapid deceleration of the inflation rate. 5

\footnotetext{
${ }^{3}$ Only anecdotal evidence is presented, based on Figures 1 to 3, so as to put the developments in the Kyrgyz Republic into perspective. The general statements in this section would warrant a more detailed, country-specific analysis in a different forum.

${ }^{4}$ For an overview on dollarization in transition economies, see Sahay and Végh (1996).

${ }^{5}$ Notwithstanding significant macroeconomic stabilization in Latvia in line with its Baltic neighbors, the CS ratio in Latvia remained high, which could be explained by its very liberal foreign exchange regulations, making it a safe haven for residents from other BRO countries. See Sahay and Végh (1996).
} 
Figure 1. Armenia, Azerbaijan, Belarus, Estonia, and Georgia: Degree of Currency Substitution and Depreciation Rate, 1993-98
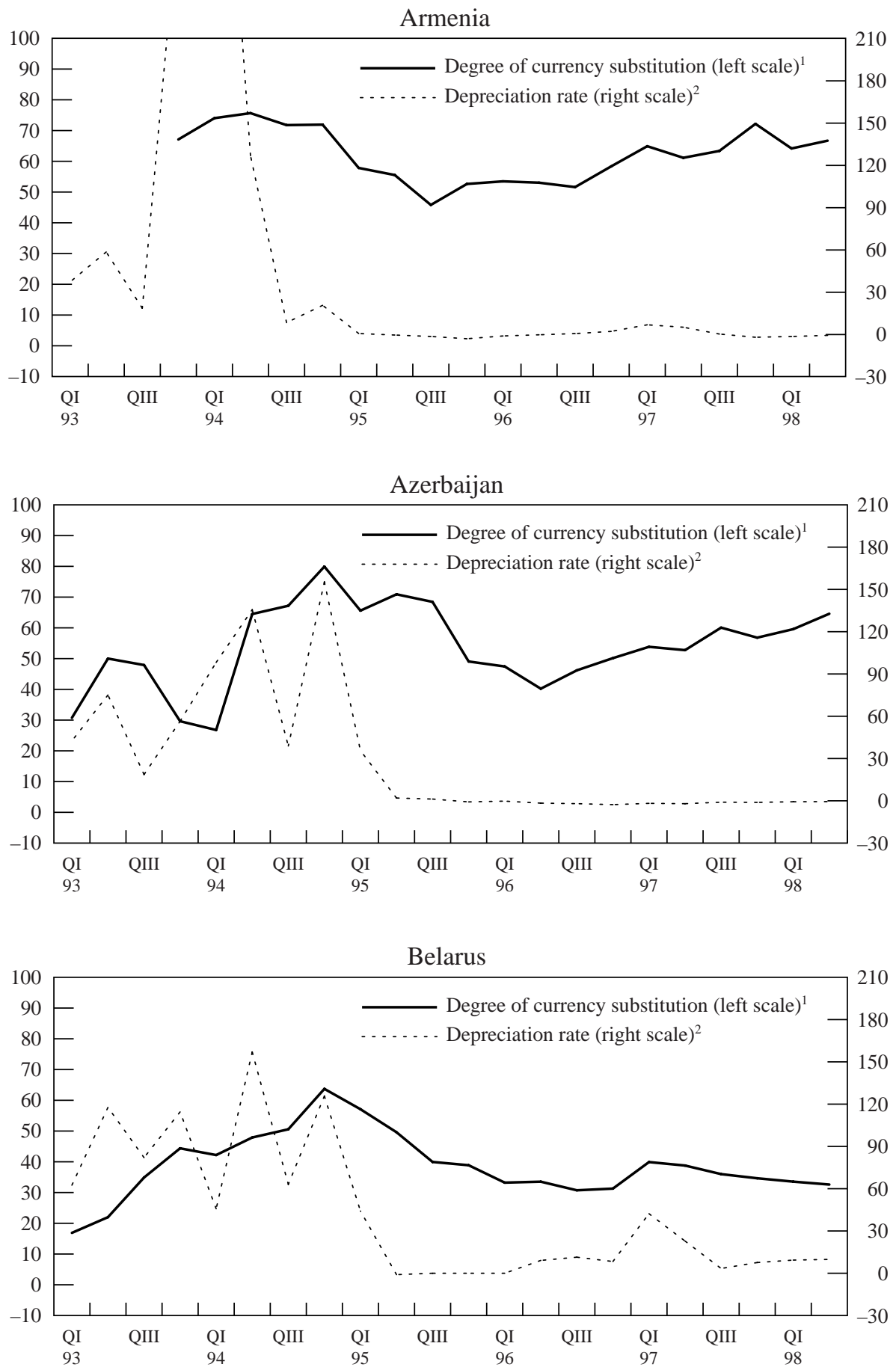
Figure 1. (concluded)
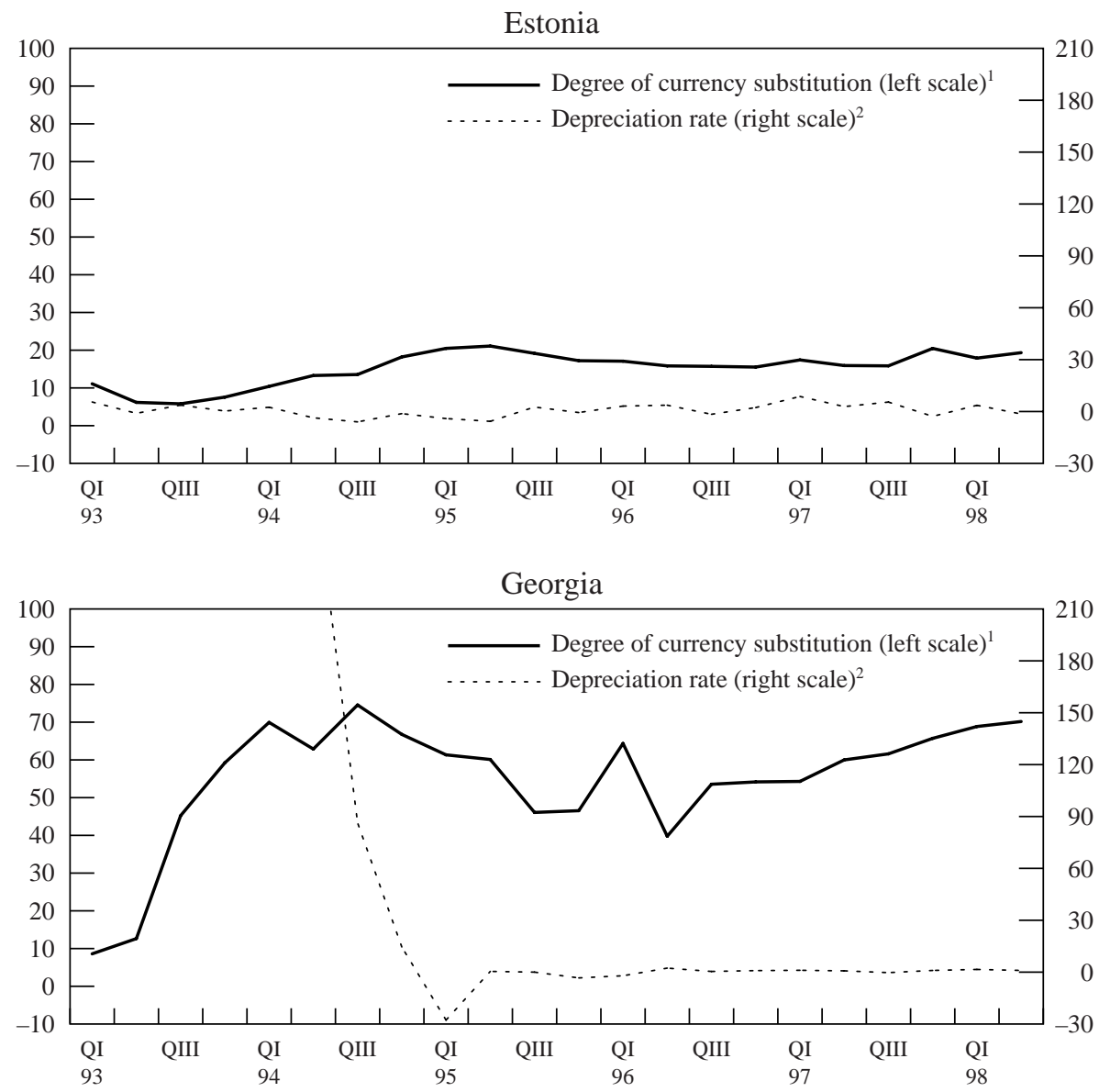

Source: IMF European II Department Common Database.

${ }^{1}$ Degree of currency substitution is defined as the ratio of foreign exchange deposits to total deposits. For some countries, the available data do not cover the entire observation period.

${ }^{2}$ Depreciation rate of domestic currency vis-à-vis the U.S. dollar.

While macroeconomic stabilization took hold in almost all of the BRO countries sooner or later, with a decline in inflation and a slowdown in the depreciation of the exchange rate, Figures 1 to 3 suggest that CS ratios, even if they have been declining, have remained at relatively high levels throughout.

It thus appears that, in line with evidence on Latin American and other countries, ${ }^{6}$ macroeconomic stabilization may have not yet induced a decline in the CS ratio in the $\mathrm{BRO}$ transition economies, with very few exceptions, like in the Baltic countries. This is somewhat in contrast to the evidence from other transition economies in Central and Eastern Europe, which experienced a substantial decline in their CS ratios, such as Poland, as pointed out by Sahay and Végh (1996). These

6For an overview, see, for example, Savastano (1992 and 1996). 
Figure 2. Kazakhstan, Kyrgyz Republic, Latvia, Lithuania, and Moldova: Degree of Currency Substitution and Depreciation Rate, 1993-98
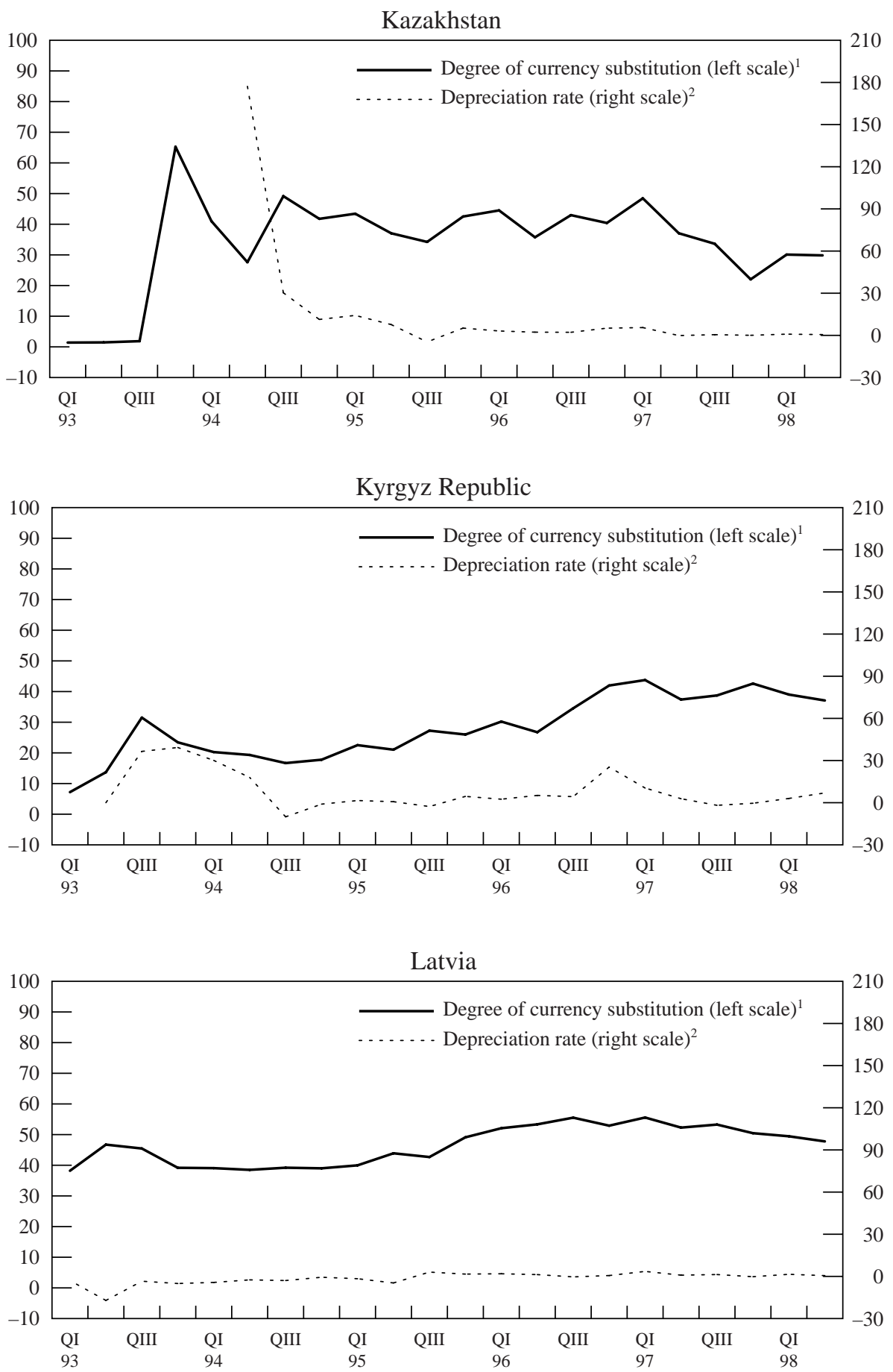
Figure 2. (concluded)
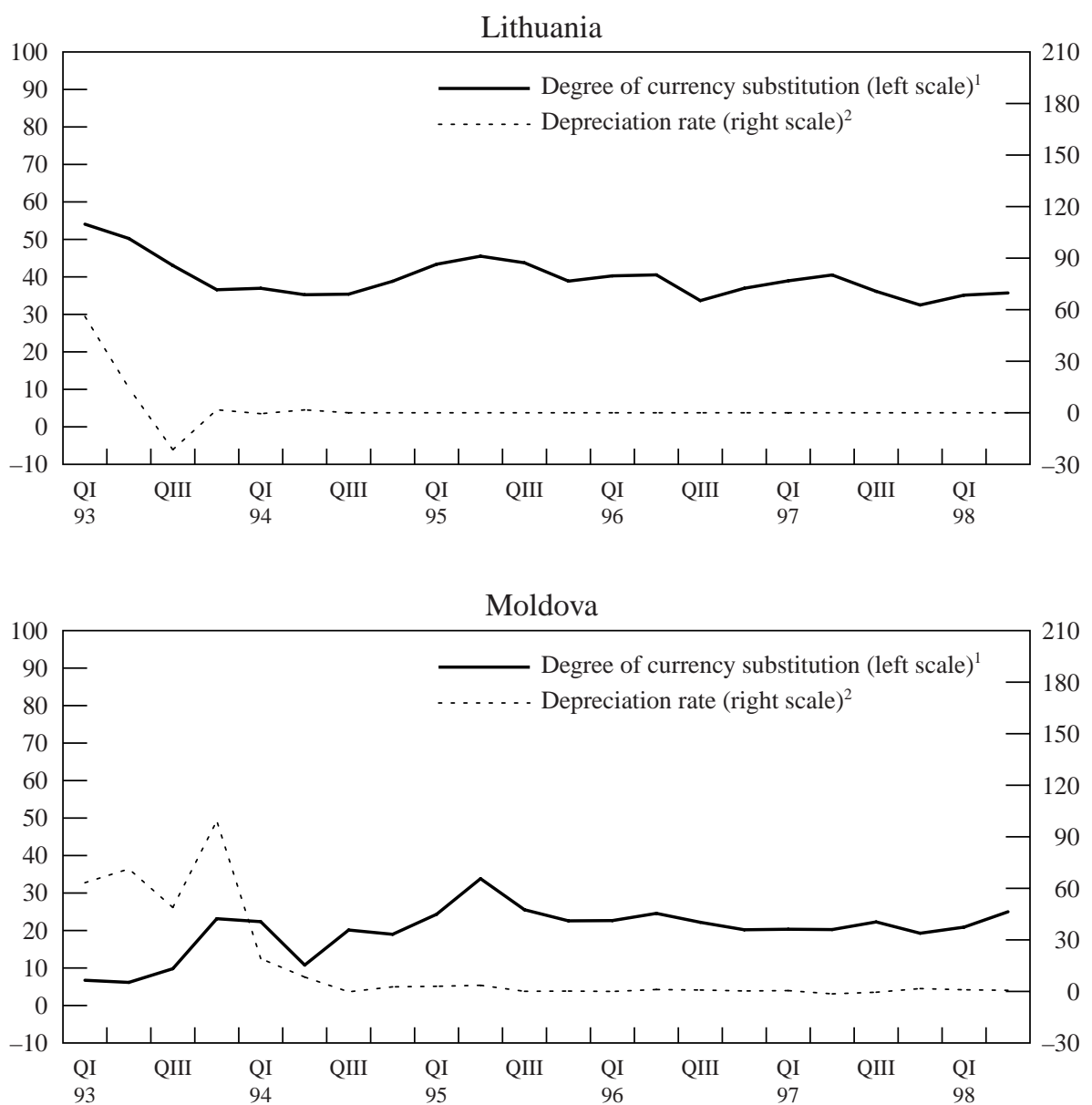

Source: IMF European II Department Common Database.

${ }^{1}$ Degree of currency substitution is defined as the ratio of foreign exchange deposits to total deposits. For some countries, the available data do not cover the entire observation period.

${ }^{2}$ Depreciation rate of domestic currency vis-à-vis the U.S. dollar.

developments appear puzzling in that developments in BRO countries could normally be expected to mirror the trends in Central and Eastern European transition economies. One possible explanation could be that, on average, Central and Eastern European countries stabilized more rapidly, implying less time for currency substitution to take hold in the economy. In turn, this would also suggest that a ratchet effect may be at work in BRO countries (Box 1).

\section{Currency Substitution in the Kyrgyz Republic}

In this section we bring the evidence of the Kyrgyz Republic to bear in this apparent puzzle. This remote Central Asian country is an interesting representative 
Figure 3. Russia, Tajikistan, Turkmenistan, Ukraine, and Uzbekistan: Degree of Currency Substitution and Depreciation Rate, 1993-98

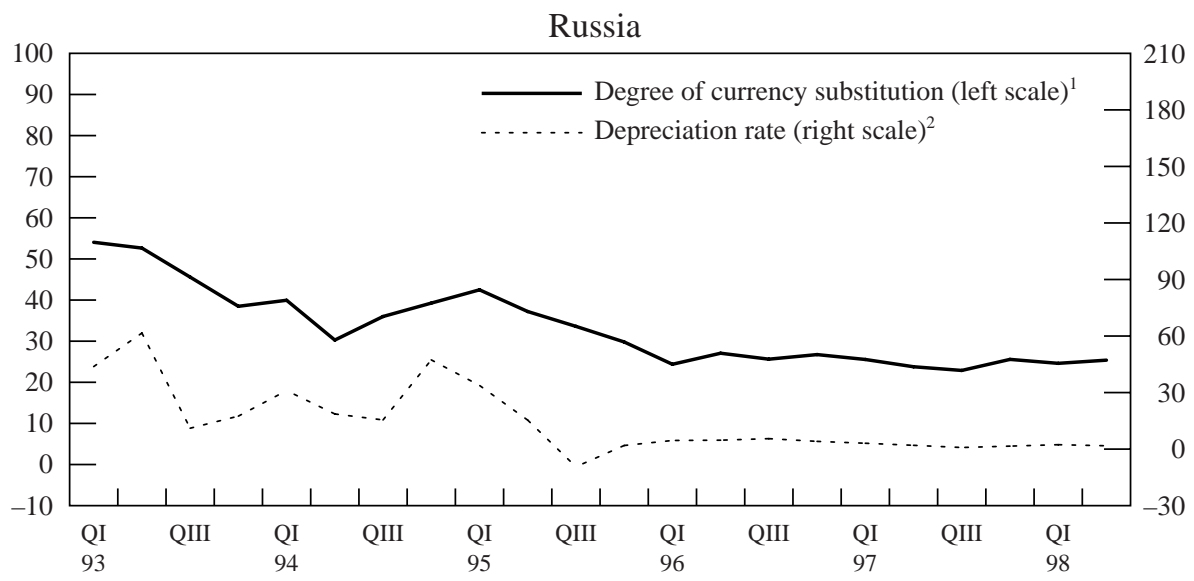

Tajikistan

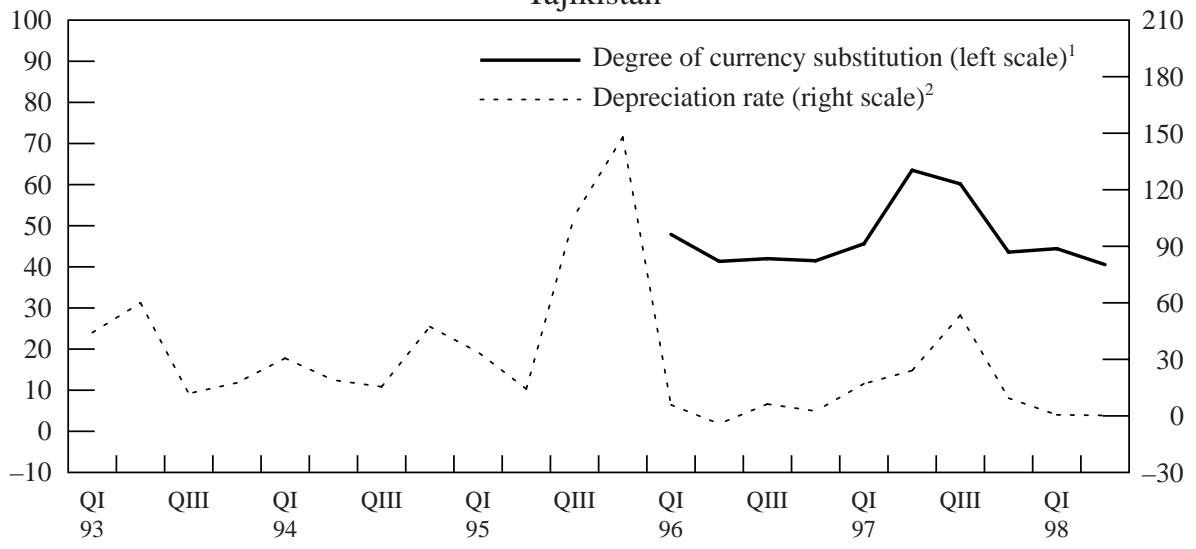

Turkmenistan

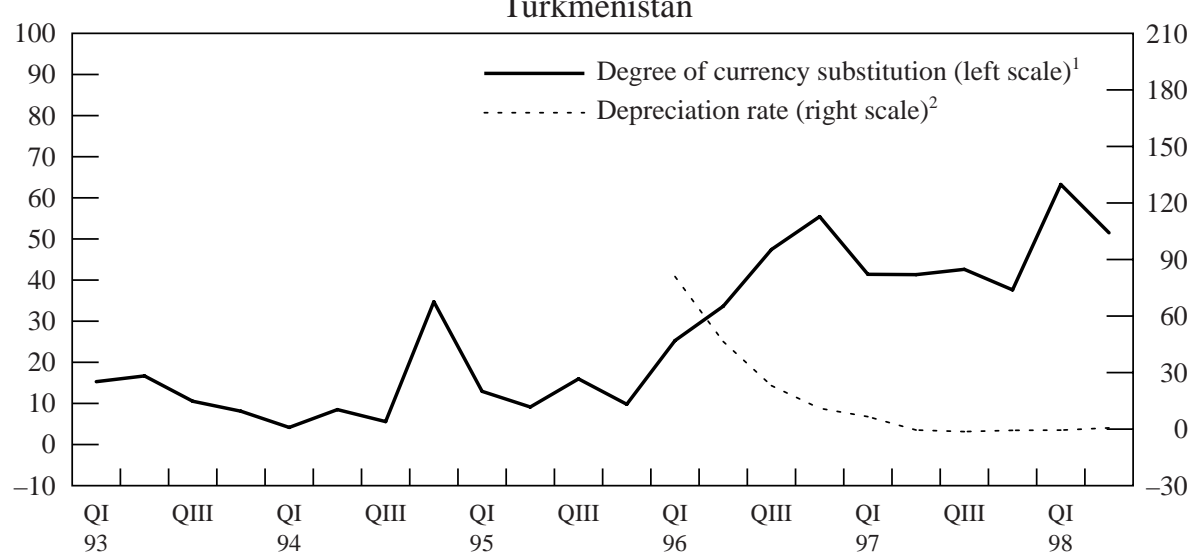


Figure 3. (concluded)
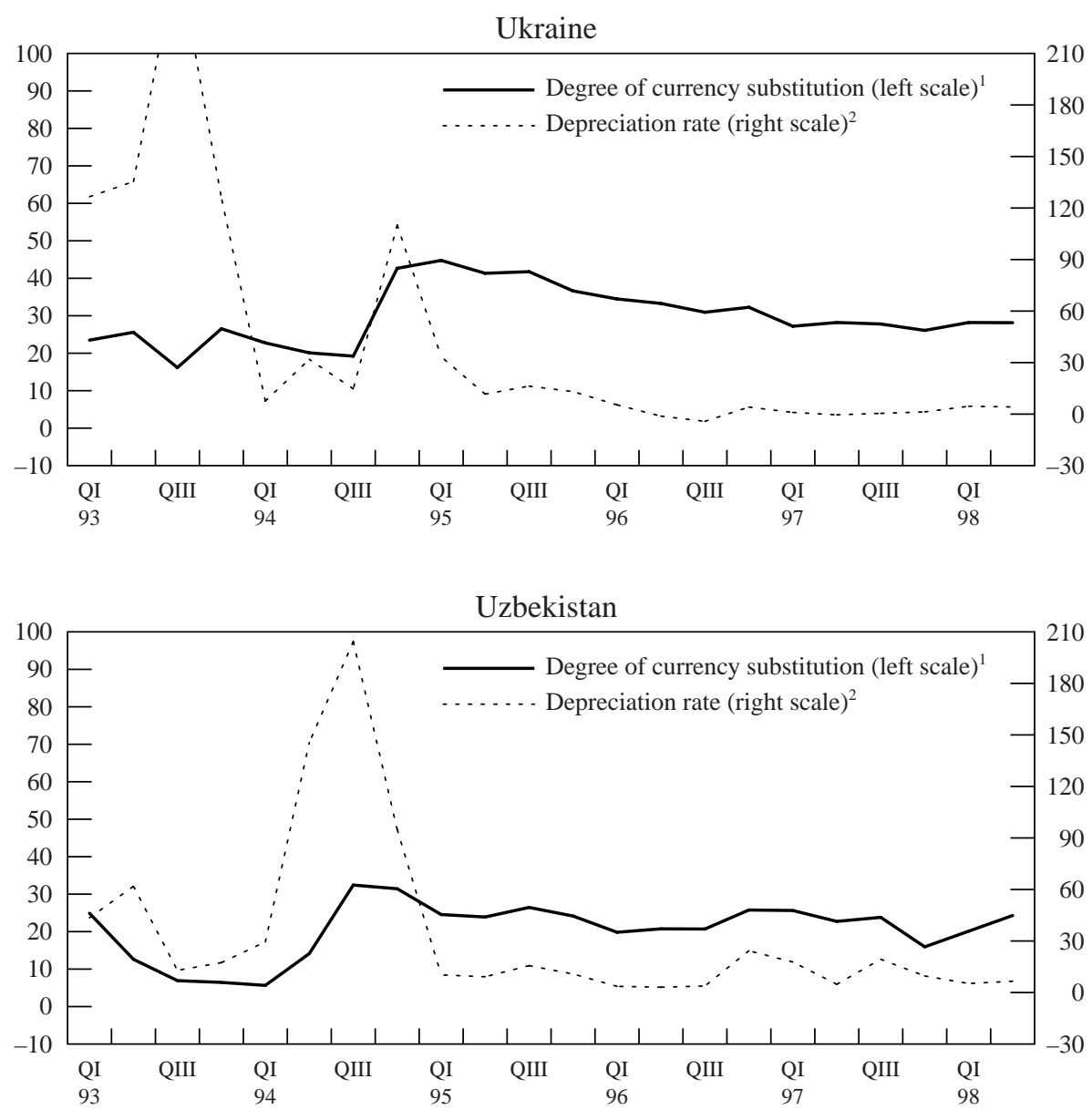

Source: IMF European II Department Common Database.

${ }^{1}$ Degree of currency substitution is defined as the ratio of foreign exchange deposits to total deposits. For some countries, the available data do not cover the entire observation period.

${ }^{2}$ Depreciation rate of domestic currency vis-à-vis the U.S. dollar.

for the group of BRO countries in that it has been one of the earliest and most active reformers within the BRO. However, notwithstanding the progress made in macroeconomic stabilization, the Kyrgyz Republic has experienced persistently high and increasing CS ratios since gaining independence (Box 2; Figure 4). The process of restoring growth and inducing disinflation in the Kyrgyz Republic as in other BRO countries is far from over, and the impact of the Russian financial crisis on BRO economies is likely to have delayed this process further. The Kyrgyz case also warrants attention in that the authorities' monitoring of the activities of foreign exchange bureaus provided access to some, albeit rough, estimates on the amount of dollar cash in circulation. 


\section{Box 1. The Ratchet Effect}

In economic models that include a ratchet effect, it is assumed that the dependent variable reacts asymmetrically to changes in one of the key explanatory variables. The ratchet effect in these models is usually accounted for through the inclusion of the past peak value of an independent variable, in addition to the current value of that variable, or of the past peak value of the dependent variable. This concept has been applied in different areas of applied economics, such as consumption theory (Duesenberry, 1952) and empirical studies on money demand in the United States (Enzler, Johnson, and Paulus, 1976; Quick and Paulus, 1979; and Simpson and Porter, 1980) and some high-inflation economies (Piterman, 1988, on Argentina, Chile, Uruguay, and Israel, as well as Melnick, 1990; Ahumada, 1992; and Kamin and Ericsson, 1993, on Argentina).

The asymmetry in the money demand function in the empirical studies on high-inflation countries was modeled by defining the ratchet variable as the past maximum of the inflation rate or, alternatively, the peak depreciation rate of the local currency. Empirical evidence from these studies suggests that hysteresis in the money demand function exists in a form such that when inflation rises to unprecedented levels, the elasticity of money demand is higher than when inflation is falling.

This asymmetric reaction of money demand to changes in the respective independent variable was attributed to cost considerations of households, i.e., the costly process of developing, learning, and applying strategies to "beat" inflation (see Dornbusch and Reynoso, 1989; Dornbusch, Sturzenegger, and Wolf, 1990; Sturzenegger, 1992; and Guidotti and Rodriguez, 1991). Once the fixed costs of deriving such strategies are borne, the new strategy remains in place and is not discarded even though interest rates, inflation rates, or depreciation rates decline again. Such strategies, commonly labeled as financial innovations, include, inter alia, the rapid switching between demand deposits and savings deposits in domestic currency, the evolution of high yielding or indexed money substitutes, the efficient use of overdrafts, the application of portfolio optimization methods, and, most notably, the flight into foreign currency assets. Over time, an increasing proportion of the public resorts to these forms of financial innovation and becomes "locked in" the new pattern even in the event of a decline in inflation or an appreciation of the exchange rate, given the large fixed costs involved in adopting these strategies, as well as their widespread use and acceptance throughout the economy. Only a significant decline in inflation or a considerable appreciation of the currency can overcome the sunk costs and provide enough incentives to eventually revert to traditional domestic money balances.

This paper uses two definitions to measure the degree of currency substitution in the Kyrgyz economy. The first measure (CS1), which is widely used in the empirical CS literature, is defined as the ratio of foreign currency deposits to total deposits in the Kyrgyz banking system and is derived from the monetary survey of the NBKR.

The second measure (CS2) is defined as the ratio of foreign currency deposits and cash to broad money plus foreign cash. Foreign-currency-denominated bills and coins circulating within an economy are generally omitted in the CS ratios of most studies. This is mainly because the stock of foreign cash in circulation within a particular country is difficult to measure and can only be roughly approximated based on generally very restrictive assumptions. ${ }^{7}$ While this caveat also applies to this study, the relatively low extent of financial intermediation in transition economies such as the Kyrgyz Republic warrants at least an attempt to capture the

${ }^{7}$ As pointed out by Savastano (1992 and 1996), some authors tried to estimate the amount of foreign currency bills in circulation in certain LDCs, e.g., Melvin and Afcha de la Parra (1989) or Kamin and Ericsson (1993). However, according to Savastano, the usefulness of these estimations is doubtful, given the extremely restrictive assumptions on the velocity of circulation of domestic money balances and other variables. 


\section{Box 2. Macroeconomic Stabilization in the Kyrgyz Republic}

After independence in 1991 and the introduction of a domestic currency, the som, in May 1993, the Kyrgyz Republic rapidly adopted a reform and adjustment strategy to transform the economy to a market system. Supported under various IMF programs, the government pursued generally tight financial policies, which over time helped reduce the annual inflation rate to single-digit levels by mid-1998.

The government also implemented a broad structural reform program to create a market-friendly environment to promote the resumption of growth driven by the private sector: most prices were liberalized, a liberal trade regime was introduced, and most capital controls were eliminated. Significant progress was also achieved in creating a two-tier banking system, leading to increasing public confidence in commercial banks until early 1999 when signs of distress in the banking system emerged.

Notwithstanding the overall macroeconomic stabilization up to mid-1998, periods of economic uncertainty and rising inflationary expectations have repeatedly reemerged, extending pressure on the exchange rate and inducing a further increase in the CS ratio. For example, the relaxation of fiscal and monetary policies in late 1995 in the run-up to the presidential election and at end-1996 led to dramatic increases in the inflation rate and a sharp depreciation of the exchange rate, which were ultimately associated with a noticeable rise of the CS ratio.

With the exchange rate stabilizing during 1997 and much of 1998 (before the Russia crisis), financial intermediation finally took off. Nevertheless, despite a near doubling of both deposits and credits during the period, the respective ratios of dollar deposits to total deposits and dollar credits to total credits have remained virtually unchanged. Banks' demand for dollar-denominated deposits appears to have also varied in line with changing needs to keep their foreign exchange exposure in check at any given point in time, leading to highly volatile interest rate spreads for som- and dollardenominated deposits over time. Hence, banks stirred to attract dollar-denominated deposits, and the interest rate differential may at times have not been sufficiently high to compensate some depositors for the expected depreciation of the domestic currency and the risk premium that inevitably is associated with a transition economy, thereby containing the decline in the CS ratio.

cash economy and compare the econometric results of this measure with the more traditional approach found in other CS studies.

The foreign cash component of CS2 was inferred by the authors by combining the stock of foreign exchange estimated in a July 1998 survey undertaken by the NBKR among foreign exchange bureaus in the capital city of Bishkek with daily data the NBKR has been collecting since January 1996 on the flows of foreign currency through these bureaus (Box 3 ).

With a view to having a sufficiently long observation period for the econometric analysis, the data were extrapolated by the authors for the period prior to January 1996 by assuming that foreign cash holdings moved proportionately to foreign currency deposits. This is equivalent to assuming that the CS ratio only moved on account of foreign currency deposits, thus avoiding any bias from the extrapolation. This assumption appears justified, since the correlation between movements of foreign exchange cash and deposits in the post-January 1996 period was quite high (at 0.8882 ).

During the observation period from the introduction of the national currency in May 1993 until October 1998, the CS1 ratio rose from about 12 percent to 45 percent; the ratio had reached its maximum of about 46 percent already in February 1997 and has since hovered at around 40 percent, with some seasonal variation. During the same period, the CS2 ratio increased from just above 10 percent to 


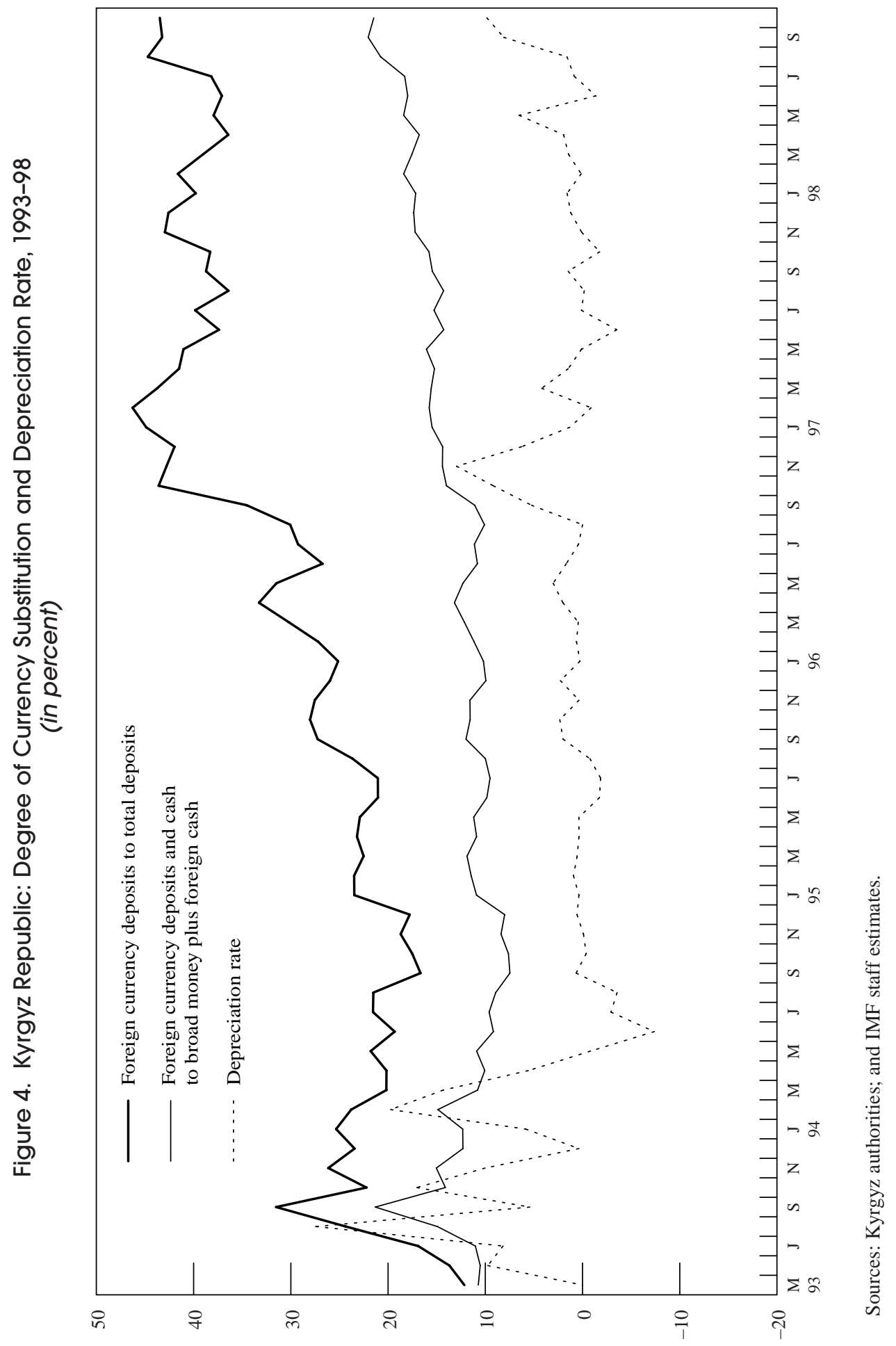




\section{Box 3. The Role of Foreign Currency Cash in the Kyrgyz Economy}

Foreign exchange bureaus are the main source for foreign currency cash in the Kyrgyz economy. As of October 1, 1998, there were 321 such offices operating in the country, of which 221 are in Bishkek and the surrounding administrative district (oblast) of Chu, 63 in the Osh oblast in the south, and the small remainder-with very little transaction volume-in the remote mountainous regions of the country. All bureaus are licensed, regulated, and supervised by the NBKR and entitled to conduct foreign exchange transactions in cash, with no prespecified limitations on volumes. Information on exchange office transactions are compiled and analyzed daily by the NBKR's Monetary Policy Department as an input for its monetary forecasting framework.

Based on the survey of July 1998, the NBKR estimated the stock of foreign currency cash circulating in the Kyrgyz Republic at about 4 percent of som-denominated currency in circulation or about 16 percent of foreign-currency-denominated deposits. Close to 90 percent of this cash was estimated to be in U.S. dollars, with the remainder being held in Russian ruble (5 percent), deutschemark ( 3 percent), and Kazakh tenge ( 2 percent).

slightly above 20 percent, exhibiting a continuous, albeit less pronounced, upward trend and less seasonal variation than the deposit-based CS ratio (Figure 4).

\section{Econometric Analysis and Results}

Most econometric studies aimed at identifying the determinants in the CS process rely on a simple structural model that is based on a standard money demand function and incorporates inflationary or exchange rate expectations or interest rate differentials as the main explanatory variables. ${ }^{8}$ The underlying assumption of this model specification is that the demand for foreign currency by residents is driven by the uncovered interest parity condition, i.e., the difference between the real rates of return on domestic and foreign currency. These, in turn, depend on the interest rate level abroad, the domestic interest rate, and expected developments in the inflation rate or the exchange rate. The econometric analysis in this paper relies on a similar model structure, ${ }^{9}$ but also includes a variable to capture the ratchet effect.

The CS model adopted here can be summarized by the following reducedform equation:

$$
C S i_{t}=\alpha+\beta_{1} \text { CSi }_{t-1-L}+\beta_{2} \text { Intdiff }_{t-L}+\beta_{3} \text { Exch }_{t-L}+\beta_{4} \text { Ratchet }_{t}+u_{t},
$$

where $C S i$ is one of the two CS ratios defined above, Intdiff is the interest differential between equivalent Treasury bills, Exch is the nominal depreciation of the exchange rate, and Ratchet is the relevant ratchet variable of the CS ratio. The $L$ indicates the optimal numbers of lags to be determined empirically through the Akaike criterion.

8See, for example, Ramirez-Rojas (1985), El-Erian (1988), Rojas-Suarez (1992), and Clements and Schwartz (1992).

${ }^{9}$ As there are no reliable monthly inflation data available especially for the first few years of the observation period, it was decided to use the monthly depreciation of the exchange rate as a proxy. The use of both the exchange rate and the inflation variables in the estimation leads to serious multicollinearity problems. 
Note that one obvious problem in estimating equation (1) above is that both CS ratios are bound by definition in the interval between 0 and 1 . Under a linear specification of the relation between CS and the independent variables, the fitted value of CS may fall outside the 0-1 range in the case of extreme values of the independent variables. A uniform transformation was therefore applied to the CS ratios in the regressions below, defined as follows:

$$
L C S i_{t}=\log _{e}\left(\frac{1-C S i_{t}}{C S i_{t}}\right),
$$

which resolves the problem without affecting the results of the regressions, except for the sign of the coefficients. Moreover, to avoid spurious results due to seasonality, both CS ratios were deseasonalized by using the residuals from a standard OLS regression with 12 seasonal dummy variables. ${ }^{10}$

As stated above, two CS measures are analyzed: the first measure (CSI) is based on deposits only, while the second measure (CS2) incorporates foreign currency cash in the analysis. The other variables used in the regressions are (a) the average monthly depreciation of the som against the U.S. dollar (Exch); (b) the interest differential (Intdiff) between the average monthly yield on threemonth Kyrgyz GKO (treasury bills) and the average monthly yield on threemonth U.S. treasury bills; and (c) a ratchet variable (Ratcs1 and Ratcs2) calculated as the maximum level of the CS1 or CS2 ratios from the beginning of the sample until one period before the current observation. The variables Exch and Intdiff were derived from the International Finance Statistics (IFS) database of the IMF.

An additional ratchet variable was also considered, defined as the maximum monthly rate of depreciation of the som against the U.S. dollar; most coefficients using this ratchet variable were nevertheless insignificant. Following Mueller (1994), the use of the CS ratchet can be justified on two grounds: first, it gradually reaches new peaks during the observation period and thus is relatively immune to outliers, thereby more accurately representing the theoretical justification behind the inclusion of the ratchet effect in the model structure (i.e., the building up of a sufficiently strong awareness threshold for the presence of large inflation and currency depreciation and the resulting process of developing, learning, and slowly beginning to apply inflation-beating money management techniques); and second, it represents all the factors - not just the role played by the exchange rate-which in the past have influenced the CS process.

\section{Econometric Procedure ${ }^{11}$}

Table 1 shows the results of the Augmented Dickey-Fuller test for each time series described above. The table indicates that the null hypothesis of a unit root can be rejected at the 95 th percentile significance level for all variables, with the

\footnotetext{
${ }^{10}$ All dummy variables in the regression for both the CS1 and CS2 ratios were statistically significant.

${ }_{11}$ All econometric results were computed using the Microfit 4.0 software package for Windows, designed by M. H. Pesaran and B. Pesaran (1997).
} 


\section{Table 1. Augmented Dickey-Fuller Tests}

Test Statistics

Variable

LCS1

LCS2

Intdiff

Exch
$-3.5195 * *$

$-2.1229$

$-4.8962 * *$

$-4.9529 * *$

** Indicates a significance level above 95 percent.

exception of $L C S 2$. In other words, LCS2 is the only variable that is not trendstationary in the sample. 12

In light of these results, it is important for the purpose of this analysis to identify an estimation procedure that can be applied regardless of the stationarity properties of the variables in the sample. A good option in this regard is to estimate equation (1) using an autoregressive distributed lag procedure (ARDL) following the methodology outlined in Pesaran and Shin (1995). This procedure estimates both short- and long-run coefficients and the variance-covariance matrix simultaneously, thus allowing for inferences on long-run estimates, which is not usually possible under alternative cointegration procedures.

The first step in the ARDL procedure by Pesaran and Shin is to test for the long-run significance of the explanatory variables. ${ }^{13}$ In the case of equation (1), it involves the testing of the joint long-run significance of the constant, the Intdiff, the Exch, and the ratchet variables. Table 2 presents the results of such a test for two different specifications of equation (1), namely without a ratchet variable (A) and with the relevant Ratcs variable (B). The tests are distributed according to a nonstandard F-statistic, which has different critical values depending on whether the dependent variable is stationary or nonstationary. ${ }^{14}$

In the case of LCS1, the long-run significance test indicates that the dependent variables are significant only at the 90th percentile. By contrast, the inclusion in the specification of the Ratcs 1 yields a significance level above the 95th percentile, indicating that the ratchet variable has considerable explanatory power in the determination of the level of the LCS1 ratio. For the second definition of the CS ratio, $L C S 2$, specification (A) without ratchet variables yields a long-run significance test above the 95th percentile significance level. The inclusion of a ratchet variable in specification (B) reduces the significance test, even though the variable Ratcs 2 keeps the significance level still above the 95th percentile. In sum, these tests give a preliminary indication that, while for the narrow CS definition (CS1) a ratchet effect may

\footnotetext{
12The tests for mean-stationarity were all rejected. LCS2 was also tested against the null hypothesis of a second order integration. The resulting test statistic was -5.738 , clearly indicating that LCS2 is integrated of order 1 .

${ }^{13}$ This test is similar in kind to testing the significance of the ECM variable in an error correction model. For details, see Pesaran and Pesaran (1997).

${ }^{14} \mathrm{~A}$ table of critical values for this nonstandard F-statistic is available in Pesaran and Pesaran (1997).
} 


\section{Table 2. Results of Long-Run Significance Tests}

(Stationary)

Dependent variables
(A) Intdiff, Exch, Constant
(B) Intdiff, Exch, Constant, Ratcs
* Indicates a significance level of 90 percent.
** Indicates a significance level of 95 percent.

$$
\text { LCS1 }
$$

LCS2

(Nonstationary)

$\begin{array}{ll}3.4228 * & 5.2506 * * \\ 4.1315 * * & 4.8908 * *\end{array}$

be significant, under a broader CS definition (CS2) there is no significant ratchet effect. In fact, this preliminary result is also confirmed in the full regressions below.

The regression results are presented in Table 3. For each specification, the table presents the error-correction (ECM) representation of the short-run estimates and the implied long-run estimates. The optimal lag length for each variable — the coefficient $L$ in equation (1) — is determined empirically by maximizing the Akaike information criterion.

Using LCSI as the dependent variable, all short-run coefficients under the various specifications are statistically significant at the 90th percentile, with the exception of the contemporaneous coefficient of $d E x c h$. This poor significance of the coefficient in the first difference of the exchange rate depreciation may be an indication that expectations in the Kyrgyz Republic are indeed adaptive, so that only lagged values of changes in the rate of depreciation have an effect on movements in the currency substitution ratio. ${ }^{15}$ The ECM coefficient is highly significant in both regressions, reflecting the joint significance of the long-run coefficients. The F-statistic is also highly significant and, as expected under the ARDL procedure, the Durbin-Watson statistic does not indicate any sign of residual serial correlation.

More important, all long-run coefficients have the expected sign and are significant at the 99th percentile significance level. In particular, note the significance of the Ratcs 1 variable in specification (B). This confirms the intuition from viewing Figure 4 and the long-run significance tests above that there may indeed be a significant ratchet effect in the portfolio decision of Kyrgyz deposit holders. Nevertheless, it should be said that the sample covers a relatively short period of time and this result would need to be confirmed over a larger sample to ensure its robustness. After all, the fit of the error-correction specification, as measured by the F-statistic, is higher when the Ratcs 1 variable is omitted. Moreover, the $\mathrm{R}^{2}$ statistic is relatively low, suggesting that other factors outside the model may have affected the CS ratio.

The impact of the ratchet effect is even more evident if shown in the context of the estimated contribution to the movements of LCS1 (Table 4). In fact, the ratchet effect accounts for 53 percent of the increase in the CS ratio, compared with 49 percent attributed to the interest rate differential and only 2 percent to the

${ }^{15}$ This result is also common to the regressions using the LCS2 ratio as a dependent variable, suggesting that this represents a more generalized phenomenon. 


\section{Table 3. Regression Results Using the ARDL Procedure} Sample Period: May 1993 to October 1998

\begin{tabular}{llll}
\multicolumn{3}{c}{ LCS1 LCS2 } \\
(A) & (B) & (A) & (B)
\end{tabular}

\section{Short-Run Coefficients: Error Correction Representation}

$\begin{array}{lcccc}\text { dINTDIFF } & 0.143 & 0.151 & 0.092 & 0.128 \\ & (3.904) & (4.137) & (1.906) & (2.593) \\ \text { dINTDIFF(-1) } & - & - & 0.027 & 0.006 \\ & - & - & (0.623) & (0.145) \\ \text { dINTDIFF(-2) } & - & - & -0.131 & 0.124 \\ & - & - & (-3.006) & (-2.918) \\ \text { dEXCH } & -0.109 & -0.214 & -0.404 & -0.597 \\ & (-0.232) & (-0.457) & (-1.073) & (-1.593) \\ \text { dEXCH(-1) } & 1.100 & 1.230 & 0.102 & 0.234 \\ & (2.083) & (2.339) & (0.247) & (0.577) \\ \text { dEXCH(-2) } & 1.602 & 1.682 & 1.009 & 0.913 \\ & (3.850) & (4.077) & (2.947) & (2.737) \\ d \text { CONST } & -0.695 & -0.185 & -0.044 & 0.797 \\ & (-2.730) & (-2.496) & (-2.432) & (2.036) \\ \text { dRATCS1 } & - & 0.195 & - & - \\ & - & (1.656) & - & - \\ \text { dRATCS2 } & - & - & - & -0.645 \\ & - & - & - & (-2.151) \\ \text { ECM(-1) } & -0.148 & -0.269 & -0.131 & -0.126 \\ & (-3.204) & (-3.127) & (-2.530) & (-2.515) \\ \text { R-squared } & 0.346 & 0.378 & 0.459 & 0.504 \\ \text { Akaike Information } \text { Criterion } & 33.852 & 34.388 & 48.397 & 50.089 \\ \text { DW-statistics } & 1.923 & 1.920 & 1.940 & 1.899 \\ \text { F-statistic } & 5.822 & 5.462 & 6.304 & 6.479 \\ & & & & \end{array}$

\section{Estimated Long-Run Coefficients}

$\begin{array}{lcccc}\text { INTDIFF } & 0.969 & 0.561 & 0.864 & 0.904 \\ & (3.633) & (3.155) & (2.619) & (2.618) \\ \text { EXCH } & -15.746 & -9.796 & -12.568 & -11.949 \\ & (-3.052) & (-3.165) & (-2.474) & (-2.413) \\ \text { CONST } & -0.470 & -0.688 & -0.338 & 6.302 \\ & (-2.832) & (-5.221) & (-1.833) & (1.545) \\ \text { RATCS1 } & - & 0.725 & - & - \\ & - & (2.681) & - & - \\ \text { RATCS2 } & - & - & - & -5.098 \\ & - & - & - & (-1.599)\end{array}$


Table 4. Relative Contributions to LCS1

$\begin{array}{lcc} & \begin{array}{c}\text { Long-Run } \\ \text { Elasticity }\end{array} & \begin{array}{c}\text { Contribution } \\ \text { (In percent) }\end{array} \\ \text { INTDIFF } & 0.561 & 49.1 \\ \text { EXCH } & -9.796 & -2.2 \\ \text { RATCS1 } & 0.725 & 53.0 \\ \text { Total } & & 100.0\end{array}$

monthly exchange rate movements. Again, this reinforces the hypothesis that asymmetric costs in currency substitution have a large impact on portfolio allocations of Kyrgyz deposit holders.

The results of the regressions with the LCS 2 ratio as a dependent variable are surprisingly similar, even though the dependent variable now includes both domestic and foreign cash holdings. There is though an important difference: the coefficient on the ratchet variable is insignificant and of the wrong sign. The short-run coefficients again are mostly significant, although some coefficients on the lags of the $d$ Exch and dIntdiff variables are below the 90th percentile significance level. The ECM variable is again significant in all specifications at the 95th percentile significance level and the F-statistic confirms the good fit of both specifications.

The similarities and differences in the results between the two measures of currency substitution (LCS1 and LCS2) become more apparent when looking at the long-run coefficients. In particular, the coefficients are quite similar between the two sets of regressions, although the Exch and Intdiff variables have a somewhat lower impact on the broader measure of currency substitution. ${ }^{16}$ More important, a marked difference from the previous results is the insignificant coefficient on the ratchet variable Ratcs 2 , suggesting that in the broader CS definition there are no ratchet effects that can be detected.

The estimated contribution to the movements of LCS 2 are shown in Table 5. Unlike the previous estimation, the effect here is more than accounted for by the interest rate differential (104 percent), while the monthly exchange rate movement again has a minor negative impact. This suggests that the policies that determine the interest rate differential can have a large impact on holdings of foreign and domestic currency and deposits.

To summarize, the econometric results show that the interest rate differential and the depreciation of the exchange rate are significant determinants of the $\mathrm{CS}$ process in the Kyrgyz economy. Moreover, while there may be a ratchet effect in the allocation of deposits, such an effect cannot be detected in the broader CS definition, confirming that the economy has not yet reached levels of "dollarization" that would imply a substantial change in the currency used to

\footnotetext{
16The latter is an expected result inasmuch as there are more factors influencing the allocation of cash holdings than just the store of value motive which drives the allocation of deposits between domestic and foreign currency (see Calvo and Végh, 1992).
} 
Table 5. Relative Contributions to LCS1

$\begin{array}{lrc}\text { Elasticity } & \begin{array}{c}\text { Contribution } \\ \text { (In percent) }\end{array} \\ \text { INTDIFF } & 0.864 & 103.8 \\ \text { EXCH } & -12.568 & -3.8 \\ \text { Total } & & 100.0\end{array}$

fulfill the transactional role of money. In this respect, policy measures may still have a strong impact on the portfolio decisions of the private sector.

\section{Conclusions}

The empirical evidence and econometric results have shown that the CS phenomenon in the Kyrgyz Republic is not yet as advanced as in the classical cases of dollarized economies. In particular, while there may be a ratchet effect in the portfolio allocation of Kyrgyz deposit holders, this effect is not detectable in the economy at large. In this respect, there may, in principle, be room for monetary policy to induce a reversal in the portfolio allocation in favor of the domestic currency by fostering a sufficiently large real interest rate differential vis-à-vis the dollar and targeting a greater stability in the exchange rate. However, the presence of a sizable ratchet effect in the deposit-only CS definition (CSI) implies that strong policies over an extended period of time would need to be pursued to convince deposit holders to switch back to som-denominated assets, while a reduction of the relative importance of foreign cash holdings may be easier and faster to achieve.

However, these results should be treated with caution for two reasons. First, the impact of the recent Russia crisis seems to have severely impacted the Kyrgyz economy and led to a further increase in currency substitution. This suggests that the scope for reversing the degree of currency substitution may have substantially been reduced. Second, the simple currency substitution model used here, augmented by the ratchet effect, can only explain about 38 to 50 percent of the CS phenomenon (as shown by the $\mathrm{R}^{2}$ statistics) depending on the CS measure used. Other factors would therefore need to be incorporated in the model before being able to conclude that monetary policy could indeed be effective in reducing the degree of currency substitution.

\section{REFERENCES}

Ahumada, H., 1992, "A Dynamic Model of the Demand for Currency: Argentina 1997-1998," Journal of Policy Modeling, Vol. 14, No. 3, pp. 335-61.

Calvo, G.A., and C. A. Végh, 1992, "Currency Substitution in Developing Countries: An Introduction," IMF Working Paper 92/40 (Washington: International Monetary Fund).

Clements, B., and G. Schwartz, 1992, "Currency Substitution: The Recent Experience of Bolivia,” IMF Working Paper 92/65 (Washington: International Monetary Fund). 
Dornbusch, R., and A. Reynoso, 1989, "Financial Factors in Economic Development," NBER Working Paper, No. 2889 (Cambridge, Massachusetts: NBER).

Dornbusch, R., F. Sturzenegger, and H. Wolf, 1990, "Extreme Inflation: Dynamics and Stabilization," Brookings Papers on Economic Activity, pp. 2-84.

Duesenberry, J., 1952, Income, Savings and the Theory of Consumer Behavior (Cambridge, Massachusetts: Harvard University Press).

El-Erian, M., 1988, "Currency Substitution in Egypt and the Yemen Arab Republic," IMF Staff Papers, Vol. 35, pp. 85-103.

Enzler, J., L. Johnson, and J. Paulus, 1976, “Some Problems of Money Demand,” Brookings Papers on Economic Activity (Washington: Brookings Institution), pp. 261-76.

Guidotti, P., and C. A. Rodriguez, 1991, "Dollarization in Latin America: Gresham Law in Reverse?," IMF Working Paper 91/113 (Washington: International Monetary Fund).

Kamin, S. B., and N. R. Ericsson, 1993, "Dollarization in Argentina," Board of Governors of the Federal Reserve System, International Finance Discussion Papers No. 460 (November).

Melnik, R., 1990, “The Demand for Money in Argentina 1978-1987: Before and After the Austral Program," Journal of Business and Economic Statistics, Vol. 8, No. 4, pp. 427-34.

Melvin, M., and G. Afcha de la Parra, 1989, "Dollar Currency in Latin America: A Bolivian Application,” Economic Letters, Vol. 31, pp. 393-97.

Mueller, J., 1994, "Dollarization in Lebanon," IMF Working Paper 94/129 (Washington: International Monetary Fund).

Pesaran, M. H., and B. Pesaran, 1997, Working with Microfit 4.0-Interactive Econometric Analysis (Cambridge: Camfit Data Ltd.).

Pesaran, M. H., and Y. Shin, 1995, “An Autoregressive Distributed Lag Modelling Approach to Cointegration Analysis," DAE Working Paper No. 9514, Department of Applied Economics (Cambridge: Cambridge University).

Piterman, S., 1988, "The Irreversibility of the Relationship Between Inflation and Real Balances," Bank of Israel Economic Review, Vol. 60, No. 1, pp. 72-83.

Quick, P. D., and J. Paulus, 1979, "Financial Innovations and the Transactions Demand for Money," Board of Governors of the Federal Reserve System, Division of Research and Statistics, Banking Section.

Ramirez-Rojas, C.L., 1985, "Currency Substitution in Argentina, Mexico, and Uruguay," IMF Staff Papers, Vol. 32, pp. 627-67.

Rojas-Suarez, L., 1992, “Currency Substitution and Inflation in Peru," IMF Working Paper 92/33 (Washington: International Monetary Fund).

Sahay, R., and C. A. Végh, 1996, "Dollarization in Transition Economies: Evidence and Policy Implications," The Macroeconomics of International Currencies: Theory, Policy, Evidence, ed. by P. Mizen and E. J. Pentecost (Cheltenham: Edward Elgar).

Savastano, M.A., 1992, "The Pattern of Currency Substitution in Latin America: An Overview," Revista de Analisis Economico, Vol. 7, No. 1, pp. 29-72.

_ 1996, "Dollarization in Latin America: Recent Evidence and Some Policy Issues," IMF Working Paper 96/4 (Washington: International Monetary Fund).

Simpson, T. D., and R. D. Porter, 1980, "Some Issues Involving the Definition and Interpretation of the Monetary Aggregates," in Federal Reserve Bank of Boston, Controlling Monetary Aggregates III, Conference Series No. 23, pp. 161-234.

Sturzenegger, F., 1992, "Inflation and Social Welfare in a Model with Endogenous Financial Adaptation,” NBER Working Paper, No. 4103 (Cambridge, Massachusetts: NBER). 